\title{
Human reproduction: possibilities and ethical borders
}

\section{Pr René Frydman}

Service de Gynécologie-Obstétrique et Médecine de la Reproduction, Hôpital Antoine Béclere, Clamart, France

\begin{abstract}
Reproductive medicine is a new important field in all the countries. The possibilities are tremendous, therefore we have to decide if limits are necessary or should we consider that everything that have been initiated (as clone, gene transfer....) can be apply in humans. That will be the challenge of a global ethical approach in each country with their culture, morality, guidelines or laws.
\end{abstract}

Key words: assisted reproductive medicine, ethics, medical progress

\section{Introduction}

The medical progress in the field of reproduction has only been possible because of parallel scientific discoveries. Development in genetics, medical imagery, hormonology, and animal reproduction applied to reproductive medicine allowed this progress. In addition, this is a new trend in our modern society which encourages infertile couples to obtain children. In this domain, reproductive medicine has been particularly efficient.

Ineluctable is no more. Everything should be possible or almost. The wish to have children is now realisable for couple who were until now with no hope. Better understanding of ovulation, spermatogenesis, news drugs (gonadotrophins, GnRH analogue: agonist or antagonist, prolactin inhibitor) contribute to ameliorate ovulation induction, and so IVF procedures. The first researches about animal reproduction started almost one century. But, we had to wait until the biologist Robert Edwards, after thirteen years of persistence and intractability, to obtain the birth of Louise Brown. This event introduced in the all world news therapeutic possibilities in infertility treatment.

In 1990, for the first time a spermatozoa has been deposed under the zona pellucida, followed later by the first intracytoplamsic sperm injection opened the treatment to the male infertility. Next step was preimplantation genetic diagnosis (PGD), allowing to select an embryo without any genetic disease.

Correspondence: R. Frydman, Univ Paris-Sud, Clamart, F-92140; AP-HP, Service de Gynécologie-Obstétrique et Médecine de la Reproduction, Hôpital Antoine Béclere, Clamart, F-92141; INSERM, U782, Clamart, F-92140
Last progress has been in vitro maturation (IVM) consisting to collect oocytes without ovarian hyperstimulation, and to make them finish their maturation in culture. This restores hope for patient with a polycystic ovary syndrome.

We are only at the beginning of new discoveries about human embryo development and its anomaly.

\section{New trends in our modern societies: ethical questions and legal aspects}

We have observed a trend to a new morality with the changes of our modern society. From this trend appeared new request like lesbian couples, transsexual, singleton parent, surrogates mother, or asks from widows. But all these new trends are not compatible with the ART laws that govern the normality of the manners. In front of these situations, the physician has no standard solution to propose, he normally has to follow the laws form his country. But he can, using his ethic sensitivity with the help of ethic committees (Epelboin et al. 2005), choose the most adapted solution directing these patients to different countries with different laws, even if his morality sensitivity is against it. This is an obligation and it brings the question to the accessibility to the best treatment for patients. For example, in Italy, no gamete donation or embryo cryopreservation is allowed, or in Germany and Norway, oocyte donation are forbidden. So what can they propose to the patients with premature ovarian failure or genetic diseases. If the best care for our patients isn't in our country we have to send our patients to others countries. This is why new legislation concerning the cross-border reproductive care has 
been recently discussed (Pennings et al. 2008). This new law 15 has for objective to reduce or limit the number of patients that have to travel abroad and to guarantee the safety and quality of the treatment wherever it is provided. Indeed in some countries very few laws govern the IVF reproduction which bring to different excesses. To fight against these practices a system of certification has to be developed. This form of civil disobedience which intends to change the existing legislation has the advantage to engage this discussion for new legislation. Now, there will be at least a partial reimbursement for treatment to ensure equitable access for all citizens, extending the probability of health insurance (ESHRE et al. law 14 2008).

The new trend of our modern society meet a hudge resistance with the ART legislation but also with religion. Sexuality and reproduction left the divine aspect to be transferred to human responsability. After working, feeding, even sexuality lost its religious traint which was present since antiquity with different gods or godesses. But this is not so simple for these religions, which solutions to reproductive problems are becoming obsolete and possibly dangerous (Mori et al. 2008). The pressure of the Vatican on Catholic universities in Belgium and in Italy to abandon IVF is mounting and is disastrous for research (Brosers et al. 2007). Religion and reproductive medicine must be separated and not interfer with the care of our patients.

The new advances in genetic research have opened the pandora's box: new possibilities of preimplantation diagnosis offer new possibilities of drifts. Indeed american physician has just proposed for couple to create a perfect child choosing, the sex, the color of his eyes, hair with preimplantation diagnosis. Indeed, preimplantation diagnosis in the United States of America are not controlled by federal laws at the differences of France. In France, therapeutic possibilities of preimplantation diagnosis are strictly controlled by the bioethic legislation. It can only be used to prevent the transmission of genetic diseases with a particular gravity or to try to obtain a cure for a precedent child with the diagnosis of HLA compatibility. This particular point is essential for the good pratice (Himmel et al. 2007, Noble et al. 2008).

\section{Next challenges}

Contrary to popular belief, infertility in resource-poor countries is a major health problem. While infertility concern between 8 and $12 \%$ of the couples, this rate go up to $30 \%$ in Sub-Saharan Africa (Pennings et al. 2009). For this reason, women may be disinherited, ostracized as they are perceived as a source of evil, subjected to physical and psychological violence and even killed. In these different countries, only richest people can have access to reproductive medicine because of the absence of any medical insurance. This inequity of basic products and health care cannot be accepted. The majority of reproductive care are concentrated in developed countries (ESHRE law 14 Human Reprod 2008). The use of public funds cannot be justified unless the costs of infertility treatment can be reduced considerably. First, infertility is directly correlated to the health policy of these differents countries. In India, the introduction of "the National Family Health Survey" in 2000 has brought the rate of infertility to $3.5 \%$ of married women against 9 to $35 \%$ for African countries. In fact, the first cause of infertility in developing countries is tubal infertility secondary to infections: 35 to 65\% in Nigeria (Otolorin et al. 1987, Otubu et al. 1990) and 77\% in South Africa (Chigumadzi et al. 1998). This pathology is directly related to the absence of any politic health care. For this reason reproductive care can't be considered without a global health policy including the education and prevention of sexual diseases like HIV or salpingitis, but also an access to contraception and family planning. So, this must include a better formation of the medical and paramedical corps. At this condition, infertility treatment can be compatible with the problem of overpopulation in these countries (Ombelet et al. 2007, 2008, Dickens et al. 2007, Prennings et al. 2009). The use of mild stimulation should allow a prevention of the risk of high rate pregnancies or hyperstimulation syndrome that should become a real medical risk in these countries. The other advantage of mild stimulation is the reduction of the economical weight.

The next challenge which has already began is the fertility conservation for the young patients suffering of a cancer. For this, new tools are actuallys studied like oocyte vitrification, oocyte and embryo cryopreservation, and the ovarian transplantation. There are already several success with livebirths after ovarian autotransplantation (Donnez et al. 2004, Andersen et al. 2008, Schmidt et al. 2005, Demeestere et al. 2006) or vitrification efficiency (Yoon et al. 2007, Kim et al. 2009).

\section{What's next?}

Reproductive medicine has for first objective to treat infertile people, but the science advancies has opened new possibilities like the cloning or the research on the stem cells. On this different points, the law has clearly decided with the interdiction of the human cloning, the study on stem cell has first been prohibited with the bioethics laws of 1994, but has been finally autorised in 2006 for the research with a special dispensation for a maximum of five years. One of the objectives is the control of cell differentiation from stem cell.

How can a stem cell be transformed in a muscular cell, a neurone or a blood cell? This knowledge should be the first step to a medical revolution: the cellular therapy (this should allow us to replace pathological cells by healthy ones directly in the organ). 
Scientific cloning, consisting to remove a cell core from an adult cell to an embryo cell for therapeutic use remains a future medical challenge. But this must inevitably pass by a precise understanding of genetics mechanisms allowing to obtain an embryo development from an adult cell core. Mechanisms of anarchic proliferation of tumoral cells may help in this understanding as it is a similar process for the cloning cells. But additional knowledge about cells programming and development are at this point necessary.

\section{Conclusion}

Our modern society is changing quickly, so we, physicians, religious, and politics have to adjust our care for our patients. In France the bioethics laws are regularly revised to try to answer to this mutation. This adaptation is necessary no to become obsolete. The next challenges are huge in particularly the development of health and ART policy in developing countries. Like the society, our reproductive medicine will know too a mutation in the next years with in particular the possibilities offered by the stem cells. But all this knowledge has to be controlled by the moral, the ethics and the laws to avoid any drift.

Very few medical specialities have such a large a wealth and interferences between its medical practice and ethical or philosophical questions. These questions had to be posed because of the evolution of our modern society.

Do we have to accept lonely women, homosexual couples nor post-menopausal patients? What about the choice of the children's sexe? Nor the surrogate mothers? Or artificial uterus? Is it reasonable to produce artificially spermatozoa nor oocyte?

Do we have to accept anything in the name of medical progress? Where does the patients freedom stop?

\section{References}

[1] Andersen CY, Rosendahl M, Byskov AG, Loft A, Ottosen C, Dueholm M, Schmidt KL, Andersen AN, Ernst E. Two successful pregnancies following autotransplantation of frozen/thawed ovarian tissue. Hum Reprod. 2008;23(10): 2266-72.

[2] Brosens I. Are Catholic universities giving up reproductive medicine? Reprod Biomed Online. 2007 Dec;15

[3] Chigumadzi PT, Moodley J, Bagratee J. Infertility profile at King Edward VIII Hospital, Durban, South Africa. Trop Doct. 1998;28(3):168-72.
[4] Demeestere I, Simon P, Buxant F, Robin V, Fernandez SA, Centner J, Delbaere A, Englert Y. Ovarian function and spontaneous pregnancy after combined heterotopic and orthotopic cryopreserved ovarian tissue transplantation in a patient previously treated with bone marrow. Transplantation: case report. Hum Reprod. 2006;21(8):2010-4.

[5] Dickens BM, Cook RJ. Reproductive health and public health ethics. Int J Gynaecol Obstet. 2007;99(1):75-9.

[6] Donnez J, Dolmans MM, Demylle D, Jadoul P, Pirard C, Squifflet J, Martinez-Madrid B, van Langendonckt A. Livebirth after orthotopic transplantation of cryopreserved ovarian tissue. Lancet. 2004;364(9443):1405-10.

[7] Epelboin S. What are the health scheme's responses to "out of the ordinary" requests in ART? J Gynecol Obstet Biol Reprod. 2005;34:S50-52.

[8] ESHRE Task Force on Ethics and Law including, Pennings G, de Wert G, Shenfield F, Cohen J, Tarlatzis B, Devroey P. Providing infertility treatment in resource-poor countries. Hum Reprod. 2009 Feb 3.

[9] ESHRE Task Force on Ethics and Law, Pennings G, de Wert G, Shenfield F, Cohen J, Tarlatzis B, Devroey P. ESHRE Task Force on Ethics and Law 14: equity of access to assisted reproductive technology. Hum Reprod. 2008;23(4):772-4.

[10] Himmel W, Michelmann HW. Access to genetic material: reproductive technologies and bioethical issues. Reprod Biomed Online. 2007

[11] Kim TJ, Laufer LR, Hong SW. Vitrification of oocytes produces high pregnancy rates when carried out in fertile women. Fertil Steril. 2009 Feb 11.

[12] Mori M. A secular perspective on 21st century ethics in human reproduction: why religious views and attitudes are becoming obsolete and possibly dangerous. Reprod Biomed Online. 2008;17.

[13] Noble R, Bahadur G, Iqbal M, Sanyal A. Pandora's box: ethics of PGD for inherited risk of late-onset disorders. Reprod Biomed Online. 2008

[14] Ombelet W, Campo R. Affordable IVF for developing countries. Reprod Biomed Online. 2007;15(3):257-65.

[15] Ombelet W, Cooke I, Dyer S, Serour G, Devroey P. Infertility and the provision of infertility medical services in developing countries. Hum Reprod Update. 2008;14(6):605-21.

[16] Otolorin EO, Ojengbede O, Falase AO. Laparoscopic evaluation of the tuboperitoneal factor in infertile Nigerian women. Int J Gynaecol Obstet. 1987;25(1):47-52.

[17] Otubu JA, Sagay AS, Dauda S. Hysterosalpingogram, laparoscopy and hysteroscopy in the assessment of the infertile Nigerian female. East Afr Med J. 1990;67(5):370-2.

[18] Pennings G, de Wert G, Shenfield F, Cohen J, Tarlatzis B, Devroey P. ESHRE task force on ethics and law 15: crossborder reproductive care. Hum Reprod. 2008;23(10):2182-4.

[19] Schmidt KL, Andersen CY, Loft A, Byskov AG, Ernst E, Andersen AN. Follow-up of ovarian function post-chemotherapy following ovarian cryopreservation and transplantation. Hum Reprod. 2005;20(12):3539-46.

[20] Yoon TK, Lee DR, Cha SK, Chung HM, Lee WS, Cha KY. Survival rate of human oocytes and pregnancy outcome after vitrification using slush nitrogen in assisted reproductive technologies. Fertil Steril. 2007;88(4):952-6. 